\title{
Smoke and Mirrors in Robotic Technocapitalism
}

\author{
Vic Grout* \\ Professor of Computing Futures, Wrexham Glyndŵr University, UK
}

Received: March 03, 2016; Accepted: March 09, 2016; Published: March 11, 2016

*Corresponding author: Professor of Computing Futures, Wrexham Glyndŵr University, Plas Coch, Mold Road, Wrexham LL11 2AW, UK. E-mail: v.grout@glyndwr.ac.uk

\section{Editorial}

Professor Stephen Hawking provoked considerable debate recently [1] by suggesting that we could have more to fear from the nature of capitalism in future than armies of intelligent robots. The response was immediate, robust, deeply personal and entirely predictable [2]. But how justified was the establishment outrage?

The basic premise of the discussion was Hawking noting that, if most of the work of a future society was performed by machines, then how we occupied ourselves instead was much more of a social, political, economic, ethical, demographic, etc. question than it was technological. The rebuttal was essentially:

1. "That's silly: the old jobs will be replaced by new ones"

2. "Please don't say nasty things about capitalism"

3. "Scientists should stick to science"

So how much of this criticism was justified and how much of it was simply 'The Establishment' [3] closing ranks?

Well, it could certainly be argued that Hawking may not have got his point across well on this occasion. He is believed to have made similar observations in previous, not-quite-soglobal environments, both in more detail and with greater clarity. Perhaps this was his fault, perhaps it was the fragmented, social media, nature of the Reddit session [4]; but the comment was easily picked up in isolation and trivialised, then reported as superficial and misrepresented as 'Those nasty capitalists are going to replace us all with robots'. It is much easier to find a counter-argument once you have repackaged the original argument in a form that suits you.

Without wishing to put words into Hawking's mouth, there are probably two key observations behind what was essentially a small soundbite:

1. The automated world we are about to enter will be very different to the present one; the traditional model of the changing workplace may not apply. If the robots take the old jobs, they may take the new ones too.
2. The numbers, the scale of all this, will be unprecedented, as may be the wider social upheaval. Alternatively, the existing economic frameworks might not change at all - which could be even worse for most people.

In both respects, people are not using the term 'singularity' lightly.

The platitudes regarding the first point generally take the form of claiming that this is apparently nothing new. True enough, we have had increasing automation in one form or another for centuries. The essential argument is that relieving humans of the mundane work, leaves them free to be more creative and find more interesting things to do. Eventually, this widening of horizons leads to both further technological advances and new jobs in these new fields. One day, technology advances to the point where these jobs themselves become automated, people go off and do something else again, and the process repeats forever ...

But it cannot repeat forever. That is not what The Technological Singularity [5] is about. We are looking ahead to a world in which machines/AI/robots - call them what you will are better than us at everything. Faster, stronger, more accurate, longer-lasting and, from a conventional economic standpoint, cheaper. They will be better at both the existing jobs for which they replace us and the new ones that arise as a result and this is the repeated pattern that we should look to - one in which humans play no part at all. Why would anyone use a human for anything if a robot can do it better? Well, there may be an answer to that but it brings us to the second point ...

In today's world already, in fact, a number of people do not work - or do very little. But, as a non-worker, how society treats you depends largely on who your parents are. It could be argued that, on the whole, current unemployment figures do not include people who do not need to work. However, whichever way you do the calculations, unemployment is generally fairly low. Most people work; and most of them work in difficult conditions, for too long, for low pay, largely for the benefit of either the more fortunate non-workers or much better-off workers. The everpresent threat is that this mundane existence is better than the 
alternative: that of becoming part of the less fortunate nonworking community. These non-workers are generally despised compared with their affluent counterparts. In fact, non-workers make up the two extremes of the social spectrum.

Now, project this model forward into a future in which the majority of people do not work. Say, for the sake of argument, that unemployment rates of $10 \%$ become more like $90 \%$. The economists will howl at these figures but the roles are reversed now: it's the economists that don't understand the significance of the technological singularity.

With existing economics, can the majority of the population be supported to do nothing? (Or meditate or write poetry or play sport or something - although there is a possibility the machines might be better at that too.) No, of course not. Because everything in the world today revolves around the competition to make profit. Nothing much happens if there is nothing in it for someone. It is very uncertain what might happen to a majority superfluous workforce. The only non-workers that will get by, just as now, will be those few that do not need to work. That simply cannot be a stable system. There is nothing essentially different to today in terms of the definitions of 'haves' and 'have-nots' but the balance will shift hugely in a numerical sense - probably well beyond the catastrophe point ... another singularity or revolution to use different terminology.

Now, if we are going to change any of this, there is some considerable thinking-outside-the-box needed here. But when scientists, who are generally pretty good at that sort of thing, dare to try, it seems that they get slapped down by economists who are all-too-ready to point out that they might not understand the niceties of current economic models. No, they probably do not. No, they are not trying to. They can see that something much bigger is about to happen and the response cannot be conventional. But when a physicist starts to talk about AI andunemployment and politics and economics, ridiculing them is very easy indeed - particularly if you are coming at it from being a beneficiary of the current system, and desperately not wanting it to change. But, it is going to have to change and to start that process involves throwing out a lot of old, comfortable assumptions about the way the world works.

Just how hard this thought revolution can be in practice, might be best illustrated by an example; essentially fictitious but not hard to associate to the real world ...

Around the turn of the millennium, there was a British car manufacturer with a strongly unionised workforce. Rampant anarcho-syndicalism it was not, but the workers did have a little more power and more say in what the company did than many elsewhere. Slowly they were able to improve their working conditions. The result was that the owners had to make more concessions to the workers, which meant less profit. Both factors led to a drop in quality in cars rolling off the production line and unrealistic prices compared to their competitors. Eventually, the company went bust. The result still stands as a case study in how not to do business. In fact, it is often noted that, by the end, 'the workers thought the company was there to give them work,

\section{rather than make cars'.}

But, can we just for a moment entertain the idea that this might be a good thing? Why should we not have structures that put people before profits? If we are not competing successfully against slave (sometimes even child) labour in other parts of the world, where really is the flaw in the system? Here or there? In a capitalist system, nothing happens unless there is a profit in it for someone; that is what drives the system - the whole world. Is it really impossible to reverse the logic? In an economic system that looked after people first, would we care that much if the cars were not much good? Well, the elite non-workers might but few others would if they were properly fed and living in peace. The elite would make diversionary claims about 'personal freedom' the rest of us would ignore them.

To put it another way, a good sub-system, failing within a bad global system, is not a bad sub-system: it points the way to a better global system.

In fact, there is work to be done, whether it be by humans or robots, but it is not being done at present because it is not profitable. Our hospitals and local amenities are falling down but they are not being rebuilt because the economics are not worthwhile. People are starving when there is food to feed them and dying when we have the medical knowhow to treat them but neither is happening because it does not pay. It cannot be denied: profit comes before people in the world today. How can it even be moral to talk about the cost of a drug that will keep someone alive? Particularly when that cost can be considerably less than the elite throw away on a whim. It cannot. It is not ethical or moral: it is economic, laced with politics. It is capitalism.

(Of course, the principle does not just apply to emerging technology. If the AI singularity does not get us first, it will be something else - perhaps environmental oblivion? Capitalism cannot and will not save the planet because no-one will profit from it and people are a secondary consideration.)

So, to return to the original 1, 2, 3 criticism of Hawking:

1. "The old jobs will be replaced by new ones." No, not this time.

2. "Don't say nasty things about capitalism." Sorry, we have to: it's going to be the death of us.

3. "Scientists should stick to science." Well yes, there is some sense in this but there is nothing worse about a scientist making social comment than an economist doing the same. The economist is simply blinkered by the belief that our society and economy are the same thing, always will be and always have to be. Escape the notion of profit being the first and last word in everything and an economist is just an expert in playing Monopoly. They have no more insight into social structures (including possibly those with robots) than a scientist, or a poet, or a footballer.

Ultimately, Hawking is right. Technology does have the potential to give us all a wonderful future. But it will not; not 
unless we are prepared to change the framework we are going to place it in. If we do not, it will make things worse.

So, 'Will the robots take our jobs?' is not the important question. (Yes, they will!) We should be asking 'What is the work that really needs to be done?', 'For whose benefit?' and 'What will we be doing while they're doing it?'

\section{References}

1. Stephen Hawking Says We Should Really Be Scared Of Capitalism, Not Robots. Huffington Post Business. 2015. http://www. huffingtonpost.com/entry/stephen-hawking-capitalism-robots us_5616c20ce4b0dbb8000d9f15
2. Stephen Hawking's Reddit AMA Shows That Richard Feynman Was Right: Just As Dumb As The Next Guy. Forbes Economics and Finance. 2015. http://www.forbes.com/sites/timworstall/2015/10/09/ stephen-hawkings-reddit-ama-shows-that-richard-feynman-wasright-just-as-dumb-as-the-next-guy/\#29649e051882

3. Owen Jones. The Establishment: And how they get away with it. 2015. Penguin.

4. Stephen Hawking. Science AMA Series: Stephen Hawking AMA Answers. 2015. The New Reddit Journal of Science.

5. Vic Grout. How Singular in the Singularity? 2015. Turing's Radiator. 